\title{
Metal selenides for photocatalytic Z-scheme pure water splitting mediated by reduced graphene oxide
}

\author{
Shanshan Chen a, Takashi Hisatomi a, Guijun Ma b,t, Zheng Wanga , Zhenhua Pan b, \\ Tsuyoshi Takata a, Kazunari Domen a,b,* \\ ${ }^{a}$ Center for Energy \& Environmental Science, Shinshu University, 4-17-1 Wakasato, Nagano-shi, Nagano 380-8553, Japan \\ ${ }^{\mathrm{b}}$ Department of Chemical System Engineering, School of Engineering, The University of Tokyo, 7-3-1 Hongo, Bunkyo-ku, Tokyo 113-8656, Japan
}

\section{A R T I C L E I N F}

\section{Article history:}

Received 22 January 2019

Accepted 17 February 2019

Published 5 November 2019

\section{Keywords:}

Hydrogen production

Photocatalysis

Selenide

Water splitting

Z-scheme

\begin{abstract}
A B S T R A C T
Exploration of novel narrow bandgap semiconductors for overall water splitting is vital for the realization of practical solar $\mathrm{H}_{2}$ production. In the work, solid solutions of zinc selenide and copper gallium selenide with absorption edge wavelengths ranging from 480 to $730 \mathrm{~nm}$ were developed. Using these metal selenides as $\mathrm{H}_{2}$-evolving photocatalysts, $\mathrm{CoO}_{x} / \mathrm{BiVO}_{4}$ as the $\mathrm{O}_{2}$-evolving photocatalyst, and reduced graphene oxide as the electron mediator, all-solid-state Z-scheme overall pure water splitting systems were constructed. The rate of photocatalytic $\mathrm{H}_{2}$ evolution from aqueous solutions containing $\mathrm{Na}_{2} \mathrm{~S}$ and $\mathrm{Na}_{2} \mathrm{SO}_{3}$ as the electron donors was evaluated while employing these selenide photocatalysts at various $\mathrm{Zn} /(\mathrm{Zn}+\mathrm{Cu})$ and $\mathrm{Ga} / \mathrm{Cu}$ molar ratios. The data demonstrate that efficient Z-scheme overall water splitting was significantly correlated to the photoelectrochemical performance of the selenide photocatalysts acting as photocathodes, rather than the photocatalytic activities of these materials during the sacrificial $\mathrm{H}_{2}$ evolution.
\end{abstract}

(C) 2019, Dalian Institute of Chemical Physics, Chinese Academy of Sciences. Published by Elsevier B.V. All rights reserved.
Photocatalytic overall water splitting is one of the most important approaches to artificial photosynthesis for solar $\mathrm{H}_{2}$ production [1-3]. The use of particulate photocatalysts is considered vital for future practical applications of this technology, based on the primary advantages such as their simplicity and cost-effectiveness [4-6]. There are two routes to photocatalytic overall water splitting by particulate photocatalysts based on one- and two-step photoexcitation processes. As a thermodynamic prerequisite, the semiconductor for a one-step photoexcitation in overall water splitting process must have conduction band minimum (CBM) and valence band maximum (VBM) energy levels that straddle the potentials of the hydrogen evolu- tion and oxygen evolution reactions. As a result, few photocatalysts have been reported capable of visible light-responsive overall water splitting [7]. In contrast, the two-step excitation system (also called the Z-scheme system) only requires that the semiconductor photocatalysts satisfy the band position condition for either the hydrogen evolution or water oxidation reaction. Therefore, this approach reduces the thermodynamic requirements and expands the choice of semiconductors, and in particular, allows the consideration of narrow bandgap materials [8]. To date, various types of visible-light-responsive photocatalysts have been applied in Z-scheme systems, including oxides, (oxy)nitrides, (oxy)sulfides, oxychlorides, and selenides

\footnotetext{
† Current Affiliation: School of Physical Science and Technology, Shanghai Tech University, Shanghai 201210, China.

* Corresponding author. Tel.+81-3-5841-1148; E-mail: domen@chemsys.t.u-tokyo.ac.jp

This work was financially supported by the Artificial Photosynthesis Project of the New Energy and Industrial Technology Development Organization (NEDO) and Grant-in-Aids for Scientific Research (A) (No. 16H02417) and Young Scientists (A) (No. 15H05494) from the Japan Society for the Promotion of Science (JSPS).

DOI: S1872-2067(19)63326-7 | http://www.sciencedirect.com/science/journal/18722067 | Chin. J. Catal., Vol. 40, No. 11, November 2019
} 
[9-14]. However, considering that the driving force for the redox reactions decreases with decreasing bandgap, the development of narrow bandgap semiconductors for efficient Z-scheme overall water splitting is still significantly challenging [15].

Metal selenides are typical narrow bandgap semiconductors and have absorption edge wavelengths longer than the corresponding metal (oxy)sulfides. This is because the VBMs of the former are typically associated with Se $4 p$ orbitals and thus, are shallower than those associated with $02 p$ and S $3 p$ orbitals. In particular, solid solutions of zinc selenide and copper gallium selenide (denoted as ZnSe:CGSe) can have tunable band structures and semiconductor characteristics, depending on the $\mathrm{Zn} /(\mathrm{Zn}+\mathrm{Cu})$ and $\mathrm{Ga} / \mathrm{Cu}$ molar ratios [13]. Recently, our group has used these metal selenides as hydrogen evolution photocatalysts (HEPs), in conjunction with $\mathrm{CoO}_{x} / \mathrm{BiVO}_{4}$ and $\mathrm{Au}$ as the oxygen evolution photocatalyst (OEP) and electron mediator, respectively, for the Z-scheme overall pure water splitting. However, this system requires the vacuum deposition of an $\mathrm{Au}$ layer. It would be preferable to avoid using expensive noble metals and to simplify the preparation technology, so as to permit the future large-scale applications of solar water splitting.

Graphene-based materials consisting of earth-abundant elements have been extensively studied because of their useful properties such as high charge carrier mobilities and exceptional conductivities [16]. It has been reported that reduced graphene oxide (RGO) can act as an electron mediator in the Z-scheme overall water splitting systems, and that such systems can be assembled simply by mixing it with an OEP under light irradiation $[17,18]$. In the present work, ZnSe:CGSe solid solutions with various $\mathrm{Zn} /(\mathrm{Zn}+\mathrm{Cu})$ and $\mathrm{Ga} / \mathrm{Cu}$ molar ratios were developed, and RGO-based powder suspension Z-scheme overall water splitting systems were constructed using $\mathrm{ZnSe}$ :CGSe photocatalysts as HEPs and $\mathrm{CoO}_{x} / \mathrm{BiVO}_{4}$ as the OEP. Both sacrificial $\mathrm{H}_{2}$ evolution and Z-scheme overall water splitting reactions were examined to improve our understanding of the most important factors involved in constructing photocatalytic Z-scheme processes involving selenide-based materials.

X-ray diffraction (XRD) patterns for $(\mathrm{ZnSe})_{x}\left(\mathrm{CuGa}_{5} \mathrm{Se}_{8}\right)_{1-x}$ solid solutions having $\mathrm{Zn} /(\mathrm{Zn}+\mathrm{Cu})$ ratios in the range $0-1$ are presented in Fig. 1a and 1b. Here, the samples having $\mathrm{Zn} /(\mathrm{Zn}+\mathrm{Cu})$ ratios of 0 and 1 correspond to $\mathrm{CuGa}_{5} \mathrm{Se}_{8}$ and $\mathrm{ZnSe}$, respectively. CuGasSes and $\mathrm{ZnSe}$ have chalcopyrite and zinc blende structures, respectively $[19,20]$. With increasing $\mathrm{Zn} /(\mathrm{Zn}+\mathrm{Cu})$ ratio, the diffraction peak at approximately $28^{\circ}$ gradually shifted to lower angles, implying the formation of a solid solution of $\mathrm{CuGa}_{5} \mathrm{Se}_{8}$ and $\mathrm{ZnSe}$ (Fig. 1b). The scanning electron microscopy (SEM) images indicated that the selenide particles had undefined morphologies, with a wide range of particle sizes starting from hundreds of nanometers to several micrometers (Fig. S1). The UV-vis diffuse reflectance spectroscopy (DRS) data showed that the absorption edge shifted to shorter wavelengths, from 675 to $480 \mathrm{~nm}$, with increasing $\mathrm{Zn} /(\mathrm{Zn}+\mathrm{Cu})$ ratio.

The effects of the $\mathrm{Ga} / \mathrm{Cu}$ molar ratio on the structural and optical properties of ZnSe:CGSe were also investigated. The selenides with a $\mathrm{Zn} /(\mathrm{Zn}+\mathrm{Cu})$ ratio of 0.5 and $\mathrm{Ga} / \mathrm{Cu}$ ratios ranging from 1.0 to 5.0 (denoted as ( $\mathrm{ZnSe})_{0.5}$ (CGSe)0.5) are discussed. Fig. $2 \mathrm{a}$ and $2 \mathrm{~b}$ show that all the diffraction peaks can be assigned to the chalcopyrite structure, suggesting the formation of solid solutions of $\mathrm{ZnSe}$ and CGSe. The shift in the main diffraction peak at $\sim 28^{\circ}$ to higher angles, with increasing $\mathrm{Ga} / \mathrm{Cu}$ ratio, is primarily ascribed to a structural rearrangement (Fig. 2b) [19]. SEM images showed that these materials had similar particle sizes, with irregular morphologies and coarse surfaces (Fig. S2). UV-vis DRS data indicated that the absorption edge shifted to shorter wavelengths with increasing $\mathrm{Ga} / \mathrm{Cu}$ ratio (Fig. 2c). A similar trend was also observed in our previous study [13].

The photocatalytic $\mathrm{H}_{2}$ evolution activities of $\mathrm{ZnSe}$ :CGSe with different compositions in the presence of $\mathrm{Na}_{2} \mathrm{~S}$ and $\mathrm{Na}_{2} \mathrm{SO}_{3}$ as sacrificial reagents were evaluated under visible light irradiation. For each selenide photocatalyst, a Ru cocatalyst was loaded at a concentration of $1 \mathrm{wt} \%$ using the photodeposition method (see Supporting Information for details). As shown in Fig. 3a, a volcano-shaped trend was observed for the rate of $\mathrm{H}_{2}$ evolution as a function of the $\mathrm{Zn} /(\mathrm{Zn}+\mathrm{Cu})$ ratio, with the maximum rate at a molar ratio of 0.5 . Based on this optimized condition, $\mathrm{Ru} /(\mathrm{ZnSe})_{0.5}(\mathrm{CGSe})_{0.5}$ photocatalysts with different $\mathrm{Ga} / \mathrm{Cu}$ ratios were evaluated. In the molar ratio range 1.0-5.0, the rate of $\mathrm{H}_{2}$ evolution increased monotonically with increas-
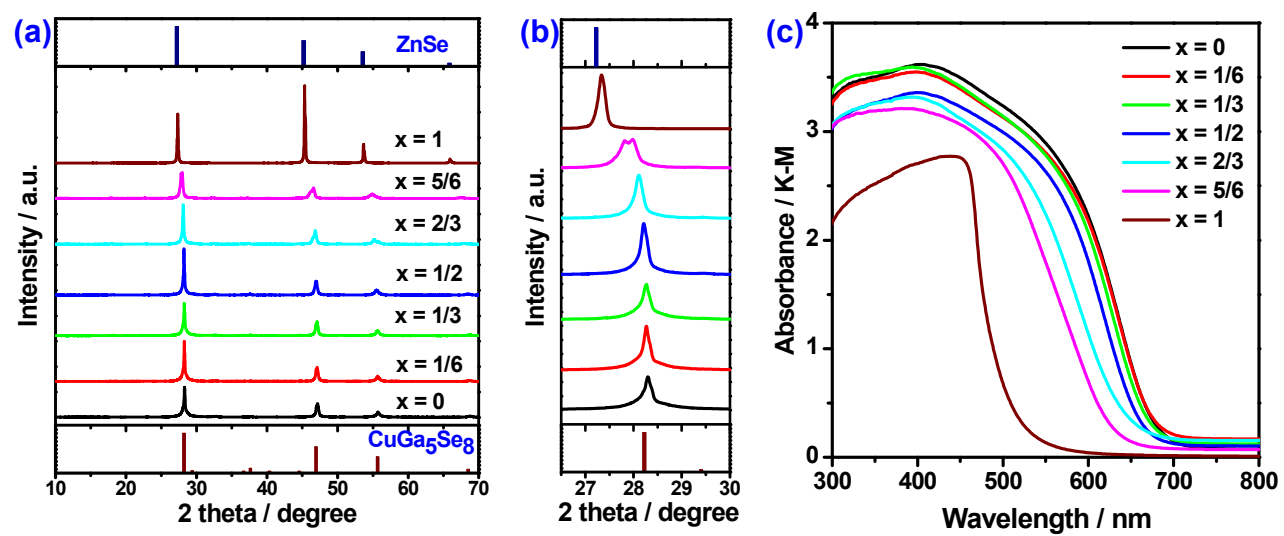

Fig. 1. (a) XRD patterns, (b) enlarged XRD patterns, and (c) UV-vis DRS data of a series of $(\mathrm{ZnSe})_{x}\left(\mathrm{CuGa}_{5} \mathrm{Se}_{8}\right)_{1-x}$ solid solutions with varying $\mathrm{Zn} /(\mathrm{Zn}+\mathrm{Cu})$ molar ratios. 

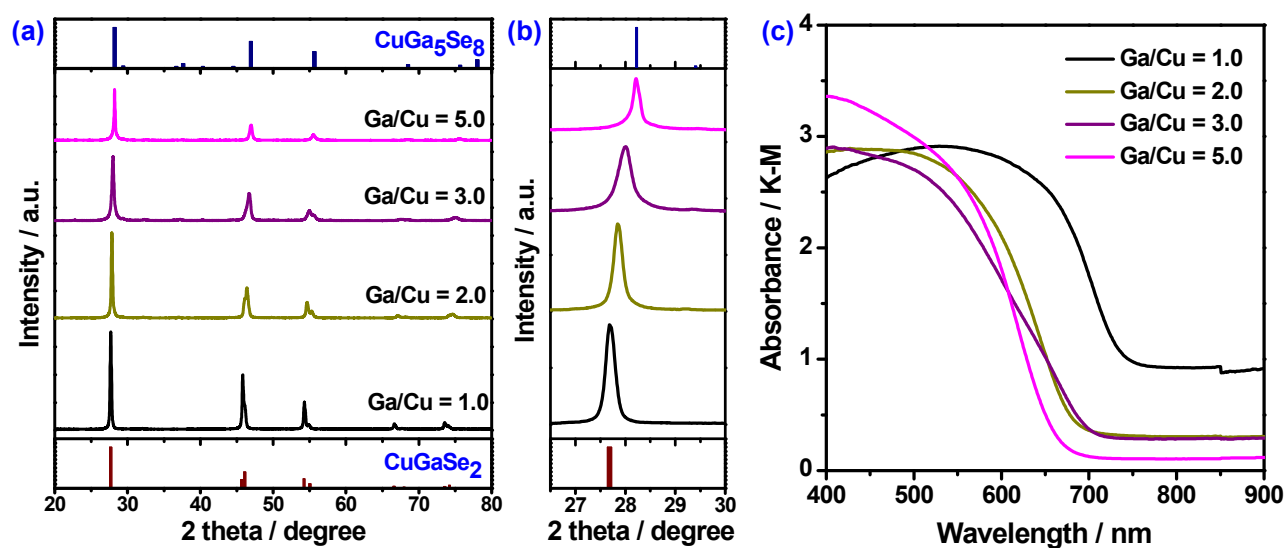

Fig. 2. (a) XRD patterns, (b) enlarged XRD patterns, and (c) UV-vis DRS data of a series of (ZnSe) (. $_{0 .}(\mathrm{CGSe})_{0.5}$ samples with varying Ga/Cu molar ratios.

ing $\mathrm{Ga} / \mathrm{Cu}$ ratio. The time courses of $\mathrm{H}_{2}$ evolution on these $\mathrm{Ru} / \mathrm{ZnSe}$ :CGSe photocatalysts (Fig. S3) also demonstrate that the catalytic activities were maintained for $5 \mathrm{~h}$, irrespective of the $\mathrm{Zn} /(\mathrm{Zn}+\mathrm{Cu})$ or $\mathrm{Ga} / \mathrm{Cu}$ ratio. The optimized $\mathrm{Ru} /(\mathrm{ZnSe})_{0.5}\left(\mathrm{CuGa}_{5} \mathrm{Se} 8\right)_{0.5}$ photocatalyst exhibited an apparent quantum yield (AQY) of $0.5 \%$ at $420 \mathrm{~nm}$. Fig. 3c summarizes the relationship between the rate of $\mathrm{H}_{2}$ evolution and the cutoff wavelength of the incident light. These data show that the onset of $\mathrm{H}_{2}$ evolution is consistent with the onset of absorption in the UV-vis DRS data, confirming that the photocatalytic $\mathrm{H}_{2}$ evolution over $\mathrm{Ru} /(\mathrm{ZnSe})_{0.5}\left(\mathrm{CuGa}_{5} \mathrm{Se} 8\right)_{0.5}$ resulted from band gap excitation. Incident light up to a wavelength of $650 \mathrm{~nm}$ could be utilized for the proton reduction reaction in the presence of this photocatalyst.

A previous work by our group demonstrated that selenide semiconductors can be used as HEPs for Z-scheme pure water splitting when they are assembled with $\mathrm{CoO}_{x}-\mathrm{BiVO}_{4}$ and $\mathrm{Au}$ as the OEP and electron mediator, respectively [13]. In such a case, the photocatalyst system was constructed in the form of a sheet, and the Au layer was prepared by vacuum evaporation. In this work, a different Z-scheme pure water splitting system incorporating a selenide-based $\mathrm{H}_{2}$-evolving photocatalyst and RGO was examined. Fig. 4a presents a schematic illustration of this new process. The primary differences in the new system are that the Au layer is replaced with RGO, and the assembled photocatalysts are in the form of a powder suspension. Thus, the assembly can be realized simply by mixing the photocatalysts together under light irradiation, without the requirement of a vacuum system. Prior to assembling the HEP and OEP in this system, a Pt reduction cocatalyst was deposited on the selenide semiconductor using an ion adsorption method [21], while RGO was deposited on the $\mathrm{CoO}_{x} / \mathrm{BiVO}_{4}$ surface (see the XRD pattern and UV-vis DRS data in Fig. S4) via photoreduction in an aqueous methanol solution (see Supporting Information for details).

Because the optimal $\mathrm{Zn} /(\mathrm{Zn}+\mathrm{Cu})$ ratio for both sacrificial $\mathrm{H}_{2}$ evolution and sheet-based overall pure water splitting was determined to be 0.5 [13], $(\mathrm{ZnSe})_{0.5}(\mathrm{CGSe})_{0.5}$ was employed to assess the effect of the $\mathrm{Ga} / \mathrm{Cu}$ ratio. As shown in Fig. $4 \mathrm{~b}$, (ZnSe) ${ }_{0.5}$ (CGSe) 0.5 photocatalysts with $\mathrm{Ga} / \mathrm{Cu}$ ratios ranging from 1.0 to 5.0 were assessed, and all the photocatalysts exhibited Z-scheme overall pure water splitting. The water splitting rate was highly dependent on the $\mathrm{Ga} / \mathrm{Cu}$ ratio and resulted in a volcano-shaped curve, with a maximum at $\mathrm{Ga} / \mathrm{Cu}$ ratio of 2.0, corresponding to an $\mathrm{H}_{2}$ evolution rate of $3.3 \mu \mathrm{mol} / \mathrm{h}$. The time courses of the overall water splitting on these photocatalysts indicated that the activities were maintained throughout the testing period of approximately $10 \mathrm{~h}$ (Fig. S5). It is worth noting that the optimized photocatalyst system generated $\mathrm{H}_{2}$ and $\mathrm{O}_{2}$ in a molar ratio close to the theoretical stoichiometric value of 2 ,
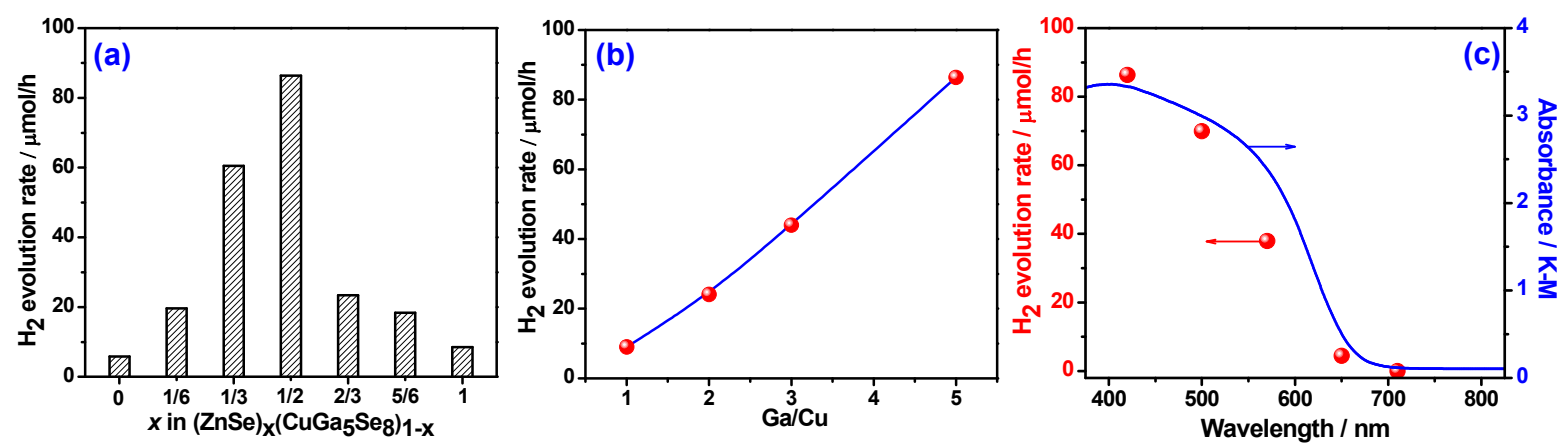

Fig. 3. Photocatalytic $\mathrm{H}_{2}$ evolution performance of a series of ZnSe:CGSe photocatalysts under visible light irradiation. (a and b) Photocatalytic $\mathrm{H}_{2}$ evolution rates of (a) $(\mathrm{ZnSe})_{x}\left(\mathrm{CuGa}_{5} \mathrm{Se}_{8}\right)_{1-x}$ samples with varying $\mathrm{Zn} /(\mathrm{Zn}+\mathrm{Cu})$ ratios and $(\mathrm{b})(\mathrm{ZnSe})_{0.5}(\mathrm{CGSe})_{0.5}$ photocatalysts with varying Ga/Cu ratios. (c) Dependence of the $\mathrm{H}_{2}$ evolution rate of $1 \mathrm{wt} \% \mathrm{Ru} /(\mathrm{ZnSe})_{0.5}\left(\mathrm{CuGa}_{5} \mathrm{Se}_{8}\right)_{0.5}$ on the cutoff wavelength of the incident light (red points) and UV-vis DRS data for $(\mathrm{ZnSe})_{0.5}\left(\mathrm{CuGa}_{5} \mathrm{Se}_{8}\right)_{0.5}$ (blue line). Experimental conditions: $0.15 \mathrm{~g}$ of photocatalyst loaded with $1 \mathrm{wt} \% \mathrm{Ru}, 0.01 \mathrm{~mol} \mathrm{~L}^{-1} \mathrm{Na}_{2} \mathrm{~S}$, and $0.01 \mathrm{~mol}$ $\mathrm{L}^{-1} \mathrm{Na}_{2} \mathrm{SO}_{3} ; 150 \mathrm{~mL} \mathrm{H} \mathrm{H}_{2} ; 300$ W Xe light; $\lambda>420 \mathrm{~nm}$. 

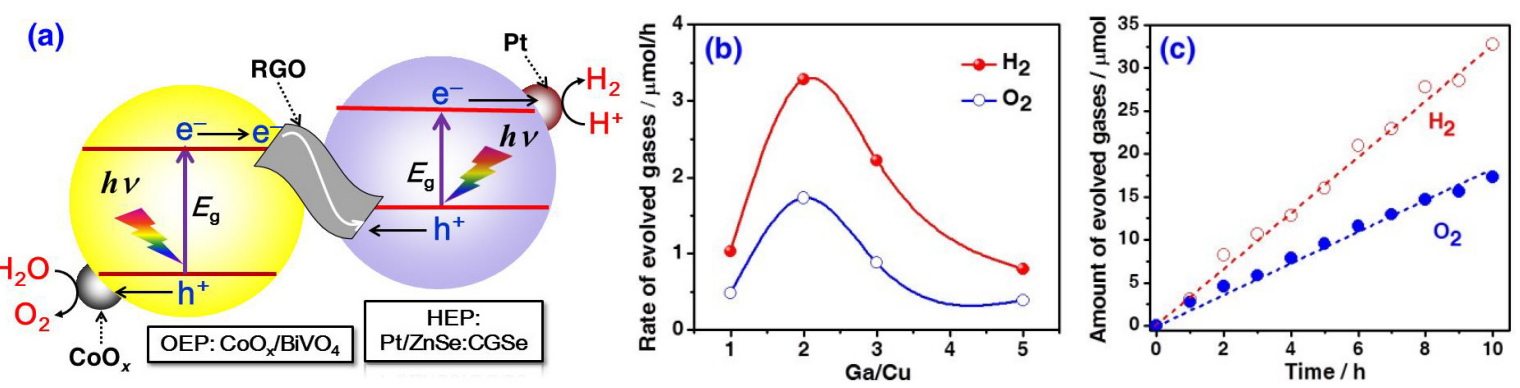

Fig. 4. Z-scheme pure water splitting with Pt/(ZnSe) ${ }_{0.5}(\mathrm{CGSe})_{0.5}$ as the HEP. (a) A schematic of the assembled Z-scheme system for photocatalytic pure water splitting. HEP: hydrogen evolution photocatalyst; OEP: oxygen evolution photocatalyst; RGO: reduced graphene oxide. (b) Rates of Z-scheme pure water splitting over $\mathrm{Pt} /(\mathrm{ZnSe})_{0.5}(\mathrm{CGSe})_{0.5} \mathrm{H}_{2}$-evolving photocatalysts having varying Ga/Cu ratios. Experimental conditions: 75 mg $\mathrm{Pt} /(\mathrm{ZnSe})_{0.5}$ (CGSe) $_{0.5}$ as the HEP, $75 \mathrm{mg} 5 \mathrm{wt} \% \mathrm{RGO}-0.5 \mathrm{wt} \% \mathrm{CoO}_{x} / \mathrm{BiVO}_{4}$ as the OEP, $150 \mathrm{~mL} \mathrm{H}_{2} \mathrm{O}, 300 \mathrm{~W}$ Xe light, $\lambda>420 \mathrm{~nm}$. (c) Time courses of the Z-scheme overall water splitting under visible light irradiation. Experimental conditions: $75 \mathrm{mg} \mathrm{Pt} /(\mathrm{ZnSe})_{0.5}(\mathrm{CuGa} 2 \mathrm{Se} .5)_{0.5}$ as the $\mathrm{HEP}, 75 \mathrm{mg} 5 \mathrm{wt} \%$ RGO-0.5 wt $\% \mathrm{CoO}_{x} / \mathrm{BiVO}_{4}$ as the OEP, $150 \mathrm{~mL} \mathrm{H}_{2} \mathrm{O}, 300 \mathrm{~W}$ Xe light, $\lambda>420 \mathrm{~nm}$.

indicating that the water splitting reaction occurred in a stable manner under visible light irradiation, with an effective suppression of the self-oxidation of $(\mathrm{ZnSe})_{0.5}\left(\mathrm{CuGa}_{2} \mathrm{Se}_{3.5}\right)_{0.5}$ (Fig. 4c). Similar to the Au layer in our previously reported photocatalyst sheet system, RGO played an important role in constructing the Z-scheme process and in stabilizing the selenide photocatalysts during the photocatalytic reaction. In this powder suspension system, photogenerated holes in the metal selenides were preferentially recombined with electrons from $\mathrm{BiVO}_{4}$ via RGO, avoiding the self-oxidation of the selenides and leading to stable pure water splitting.

Interestingly, the sacrificial $\mathrm{H}_{2}$ evolution rate was found to increase monotonically with increasing $\mathrm{Ga} / \mathrm{Cu}$ ratio, while a volcano-shaped trend was observed in the Z-scheme water splitting rate as a function of the $\mathrm{Ga} / \mathrm{Cu}$ ratio (Fig. $3 \mathrm{~b}$ and $4 \mathrm{~b}$ ). That is to say, the activities of the sacrificial $\mathrm{H}_{2}$ evolution and Z-scheme overall water splitting reactions were not linearly correlated. Our previous study showed that increasing the $\mathrm{Ga} / \mathrm{Cu}$ ratio also increased the band gap energy of $(\mathrm{ZnSe})_{0.5}(\mathrm{CGSe})_{0.5}$. This effect was primarily due to a positive shift in the VBM potentials of these materials, which in turn allowed holes to be consumed more efficiently in response to the oxidation of the sacrificial reagents, owing to the greater driving force [13]. As a result, the photogenerated electrons were able to avoid recombination with holes and thus, contributed to the hydrogen evolution more efficiently, despite an approximate increase of $0.2 \mathrm{eV}$ in the band gap energy. In contrast, the Z-scheme water splitting activity of the RGO-based powder suspension system examined in the present study varied with the $\mathrm{Ga} / \mathrm{Cu}$ ratio in a manner similar to that for the Z-scheme-type photocatalyst sheet based on an Au conductor layer. The latter can be regarded as an assembly of numerous miniature $p-n$ photoelectrochemical (PEC) cells [13]. Thus, this similarity suggests that the photocatalytic performance of the assembled unit consisting of an HEP, an OEP, and RGO is closely related to the PEC performance of such units. Therefore, the excellent PEC characteristics of the selenide-based materials are evidently responsible for the efficient Z-scheme activities exhibited by this powder suspension photocatalyst system $[21,22]$.

In summary, ZnSe:CGSe have been found to act as an HEP in a powder suspension Z-scheme overall pure water splitting system, when combined with $\mathrm{CoO}_{x} / \mathrm{BiVO}_{4}$ and RGO as the OEP and electron mediator, respectively. This is the first report of visible light-driven photocatalytic Z-scheme pure water splitting using a powder suspension that involves metal selenides with narrow bandgaps. A nonlinear relationship was observed between the photocatalytic activities during the Z-scheme overall water splitting and sacrificial $\mathrm{H}_{2}$ evolution reactions. Based on the similar reaction characteristics of the present RGO-based Z-scheme system and a previously reported photocatalyst sheet system, it was revealed that selenide photocatalysts exhibiting high photocathodic currents at positive potentials when serving as photocathodes, should exhibit more efficient Z-scheme overall pure water splitting.

\section{References}

[1] A. Kudo, Y. Miseki, Chem. Soc. Rev., 2009, 38, 253-278.

[2] Y. Tachibana, L. Vayssieres, J. R. Durrant, Nat. Photonics, 2012, 6 , 511-518.

[3] S. Chen, Y. Qi, C. Li, K. Domen, F. Zhang, Joule, 2018, 2, 2260-2288.

[4] D. M. Fabian, S. Hu, N. Singh, F. A. Houle, T. Hisatomi, K. Domen, F. E. Osterloh, S. Ardo, Energy Environ. Sci., 2015, 8, 2825-2850.

[5] S. Chen, T. Takata, K. Domen, Nat. Rev. Mater., 2017, 2, 17050.

[6] D. Kong, Y. Zheng, M. Kobielusz, Y. Wang, Z. Bai, W. Macyk, X. Wang, J. Tang, Mater. Today, 2018, 21, 897-924.

[7] Z. Wang, C. Li, K. Domen, Chem. Soc. Rev., 2018, doi: 10.1039/C8CS00542G.

[8] Y. Wang, H. Suzuki, J. Xie, O. Tomita, D. J. Martin, M. Higashi, D. Kong, R. Abe, J. Tang, Chem. Rev., 2018, 118, 5201-5241.

[9] K. Maeda, ACS Catal., 2013, 3, 1486-1503.

[10] S. Chen, Y. Qi, T. Hisatomi, Q. Ding, T. Asai, Z. Li, S. S. K. Ma, F. Zhang, K. Domen, C. Li, Angew. Chem. Int. Ed., 2015, 54, 8498-8501.

[11] G. Ma, S. Chen, Y. Kuang, S. Akiyama, T. Hisatomi, M. Nakabayashi, N. Shibata, M. Katayama, T. Minegishi, K. Domen, J. Phys. Chem. Lett., 2016, 7, 3892-3896.

[12] H. Fujito, H. Kunioku, D. Kato, H. Suzuki, M. Higashi, H. Kageyama, R. Abe, J. Am. Chem. Soc., 2016, 138, 2082-2085.

[13] S. Chen, G. Ma, Q. Wang, S. Sun, T. Hisatomi, T. Higashi, Z. Wang, M. Nakabayashi, N. Shibata, Z. Pan, T. Hayashi, T. Minegishi, T. Takata, K. Domen, J. Mater. Chem. A, 2019, doi: 10.1039/C9TA00768G. 


\title{
Graphical Abstract
}

Chin. J. Catal., 2019, 40: 1668-1672 doi: S1872-2067(19)63326-7

Metal selenides for photocatalytic Z-scheme pure water splitting mediated by reduced graphene oxide

Shanshan Chen, Takashi Hisatomi, Guijun Ma, Zheng Wang, Zhenhua Pan,

Tsuyoshi Takata, Kazunari Domen*

Shinshu University, Japan; The University of Tokyo, Japan

Powder suspension Z-scheme pure water splitting systems employing narrow bandgap metal selenides, $\mathrm{CoO}_{x} / \mathrm{BiVO}_{4}$, and reduced graphene oxide as the $\mathrm{H}_{2}$ evolving photocatalyst, $\mathrm{O}_{2}$ evolving photocatalyst, and electron mediator, respectively, are demonstrated.

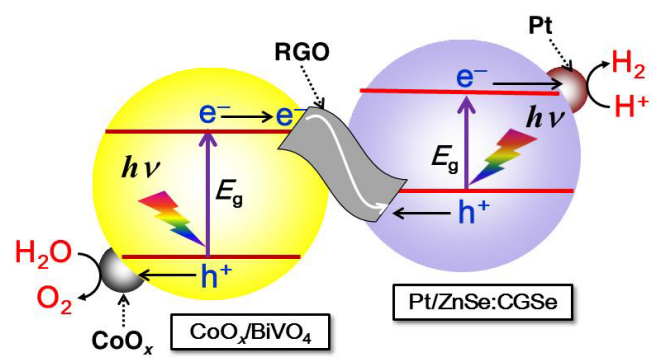

[14] Z. Song, T. Hisatomi, S. Chen, Q. Wang, G. Ma, S. Li, X. Zhu, S. Sun, K. Domen, ChemSusChem, 2019, doi:10.1002/cssc.201802306.

[15] S. Chen, F. Zhang, Chin. J. Catal., 2014, 35, 1431-1432.

[16] Q. Xiang, J. Yu, M. Jaroniec, Chem. Soc. Rev., 2012, 41, 782-796.

[17] A. Iwase, Y. H. Ng, Y. Ishiguro, A. Kudo, R. Amal, J. Am. Chem. Soc., 2011, 133, 11054-11057.

[18] Z. Pan, T. Hisatomi, Q. Wang, S. Chen, A. Iwase, M. Nakabayashi, N. Shibata, T. Takata, M. Katayama, T. Minegishi, A. Kudo, K. Domen,
Adv. Funct. Mater., 2016, 26, 7011-7019.

[19] H. Kumagai, T. Minegishi, Y. Moriya, J. Kubota, K. Domen, J. Phys. Chem. C, 2014, 118, 16386-16392.

[20] S. Adachi, T. Taguchi, Phys. Rev. B, 1991, 43, 9569-9577.

[21] K. Iwashina, A. Iwase, Y. H. Ng, R. Amal, A. Kudo, J. Am. Chem. Soc., 2015, 137, 604-607.

[22] A. Iwase, S. Yoshino, T. Takayama, Y. H. Ng, R. Amal, A. Kudo, J. Am. Chem. Soc., 2016, 138, 10260-10264.

\section{金属硒化物用于以石墨烯为电子介质的光催化Z机制全分解水体系}

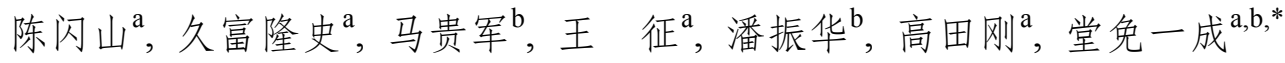 \\ a信州大学能源与环境科学中心, 长野3808553, 日本 \\ b东京大学工学院, 东京1138656, 日本
}

摘要: 基于粉末半导体催化剂的太阳能光催化分解水技术因具有廉价和适宜大规模生产等优点正日益成为未来重要的制 氢技术之一. 开发高效光催化分解水体系的一个重要前提是使用窄带隙半导体材料, 从而能最大化地吸收和利用太阳光 谱. 近年来, 一些诸如氮(氧)化物、硫(氧)化物和硒化物等窄带隙半导体材料陆续被开发和拓展到光催化全分解水体系中. 然而, 考虑到随着吸收波长的提高而导致氧化还原反应驱动力减小的挑战, 开发基于窄带隙半导体催化剂的高效全分解水 体系依然是当今光催化研究领域的主题之一.

金属硒化物作为一类窄带隙半导体材料, 较同类氧化物和硫化物具有更长的吸收带边. 前期我们课题组利用金层针 定的硒化锌和铜镓硒固溶体 $\left(\mathrm{ZnSe}: \mathrm{CGSe}\right.$ )产氢催化剂与 $\mathrm{CoO}_{x} / \mathrm{BiVO}_{4}$ 产氧催化剂组合实现了首例基于硒化物的可见光驱动 $\mathrm{Z}$ 机制全分解纯水. 为了进一步探索更多基于硒化物构筑Z机制全分解水催化体系的可能, 本文通过调变 $\mathrm{Zn} /(\mathrm{Zn}+\mathrm{Cu})$ 和 $\mathrm{Ga} / \mathrm{Cu}$ 摩尔比制备了吸收带边在480-730 nm范围内可调的系列 ZnSe:CGSe样品, 并以此硒化物为产氢催化剂, 结合 $\mathrm{CoO}_{x} / \mathrm{BiVO}_{4}$ 产氧催化剂以及还原石墨烯(RGO)电子介质成功构筑了另一种Z机制全分解纯水催化体系. 该体系与前期报 道的体系相比, 避免了真空蒸镀工艺过程, 构筑起来更为简单便捷. 研究表明, 光催化分解水效率与对应硒化物光阴极的 光电性能密切相关, 而与有牺牲试剂存在下的硒化物产氢活性不呈线性关系.

关键词: 产氢; 光催化; 硒化物; 水分解; Z机制

收稿日期: 2019-01-22. 接受日期: 2019-02-17. 出版日期: 2019-11-05.

*通讯联系人. 电话: +81-3-5841-1148; 电子信箱: domen@chemsys.t.u-tokyo.ac.jp 本文的电子版全文由Elsevier出版社在ScienceDirect上出版(http://www.sciencedirect.com/science/journal/18722067). 